\title{
An intriguing case of blurred vision in a young patient
}

A Walkden, ${ }^{1}$ J Morarji, ${ }^{2}$ K Smyth ${ }^{3}$

${ }^{1}$ Department of Ophthalmology, NHS England, Preston, Lancashire, UK ${ }^{2}$ NHS England, Preston, Lancashire, UK

${ }^{3}$ Bolton Eye Unit, NHS England, Bolton, UK

\section{Correspondence to}

Dr A Walkden,

andrew.walkden@nhs.net

Accepted 19 November 2014
To cite: Walkden $\mathrm{A}$, Morarji J, Smyth K. BMJ Case Rep Published online: [please include Day Month Year] doi:10.1136/bcr-2014207445

\section{DESCRIPTION}

A 25 -year-old man with homocystinuria (HCU) presented with a 6-month history of blurred vision. His acuity measured 6/6 (20/20) bilaterally with spectacle correction. Examination found bilateral, inferior subluxation of the crystalline lens with zonular disruption (figure 1).

\section{DISCUSSION}

HCU is an autosomal recessive disorder of methionine metabolism, with an incidence of 1/100 000, resulting in systemic accumulation of homocysteine.

Features include blonde hair, blue irides, marfanoid habitus and arachnodactyly. Neurodevelopmental delay can accompany these features. If suspected, urine screening for cyanide nitroprusside is undertaken. The Guthrie heel-prick test during neonatal screening also detects high methionine levels.

Displacement of the crystalline lens (ectopia lentis), typically occurs inferonasally in untreated HCU by age 25 . The lens zonules (suspensory ligaments) contain cysteine but if replaced by homocysteine, disintegration occurs (figure 2). Retinal detachment and optic atrophy is associated. ${ }^{1}$ Raised homocysteine levels can cause carotid stenosis, low vitamin $\mathrm{B}_{12}$ levels and thrombogenesis, making secondary stroke prevention crucial. ${ }^{2}$

Treatment involves vitamin $\mathrm{B}_{6}$ supplementation. Ocular management is conservative if symptoms are tolerated. Surgical intervention involves removal of the crystalline lens with intraocular lens implantation. Iris or scleral fixated lenses may be

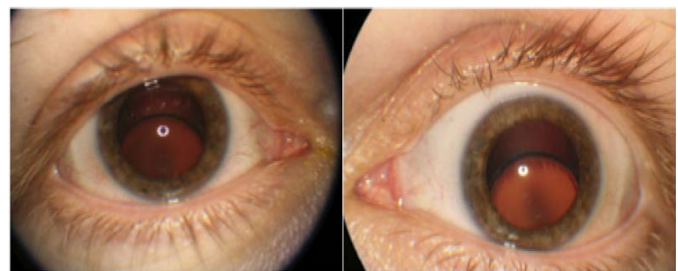

Figure 1 Bilateral ectopia lentis. The zonular suspensory fibres are deficient in cysteine, making them weak and leading to lenticular dislocation.

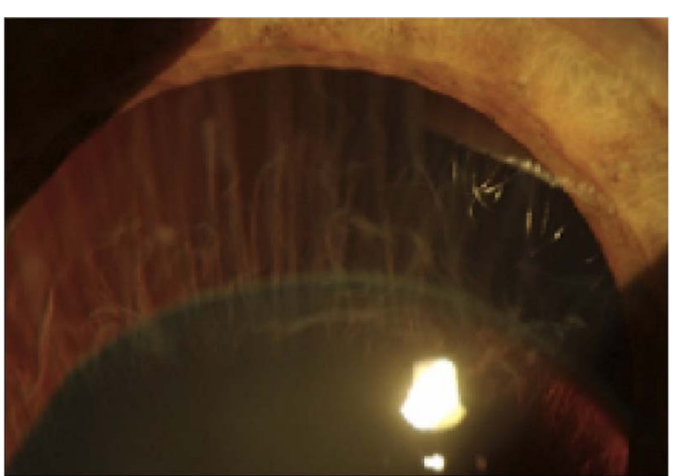

Figure 2 Magnified image of lens zonules (suspensory ligaments).

considered. Intraocular pressure needs to be controlled if the iridocorneal angle becomes involved. ${ }^{3}$

\section{Learning points}

Systemic pathology must be considered if lens dislocation occurs. As with this case, Snellen visual acuity may not be severely affected. Light entering the peripheral lens instead of the true optical centre causes symptomatic image blurring.

Contributors AW wrote the initial manuscript. JM and KS helped with the revision and editing to produce the final manuscript.

Competing interests None.

Patient consent Obtained.

Provenance and peer review Not commissioned; externally pee reviewed.

\section{REFERENCES}

1 Yoo JH, Chung CS, Kang SS. Relation of plasma homocyst(e)ine to cerebral infarction and cerebral atherosclerosis. Stroke 1998;29:2478-83.

2 Bakker RC, Brandjes DP. Hyperhomocysteinaemia and associated disease. Pharm World Sci 1997:19:126-32.

3 Kanski J, Bowling B. Clinical ophthalmology: a systematic approach: expert consult. 7th edn. Elsevier, 2011. 
Copyright 2015 BMJ Publishing Group. All rights reserved. For permission to reuse any of this content visit http://group.bmj.com/group/rights-licensing/permissions.

BMJ Case Report Fellows may re-use this article for personal use and teaching without any further permission.

Become a Fellow of BMJ Case Reports today and you can:

- Submit as many cases as you like

- Enjoy fast sympathetic peer review and rapid publication of accepted articles

- Access all the published articles

- Re-use any of the published material for personal use and teaching without further permission

For information on Institutional Fellowships contact consortiasales@bmjgroup.com

Visit casereports.bmj.com for more articles like this and to become a Fellow 